\title{
Navigating the dilemmas of climate policy in Europe: evidence from policy evaluation studies
}

\author{
Constanze Haug • Tim Rayner • Andrew Jordan • Roger Hildingsson • \\ Johannes Stripple • Suvi Monni • Dave Huitema • Eric Massey • \\ Harro van Asselt $\cdot$ Frans Berkhout
}

Received: 28 August 2008 / Accepted: 28 July 2009 / Published online: 13 October 2009

(C) The Author(s) 2009. This article is published with open access at Springerlink.com

\begin{abstract}
Climate change is widely recognised as a 'wicked' policy problem. Agreeing and implementing governance responses is proving extremely difficult. Policy makers in many jurisdictions now emphasise their ambition to govern using the best available evidence. One obvious source of such evidence is the evaluations of the performance of existing policies. But to what extent do these evaluations provide insights into the difficult dilemmas that governors typically encounter? We address this question by reviewing the content of 262 evaluation studies of European climate policies in the light of six kinds of dilemma found in the governance literature. We are interested in what these studies say about the performance of European climate policies and in their capacity to inform evidence-based policy-making. We find that the evaluations do arrive at common findings: that climate change is framed as a problem of market and/or state failure; that voluntary measures tend to be ineffective; that market-based instruments tend to be regressive; that EUlevel policies have driven climate policies in the latecomer EU Member States; and that lack of monitoring and weak enforcement are major obstacles to effective policy implementation. However, we also conclude that the evidence base these studies represent is surprisingly weak for such a high profile area. There is too little systematic climate policy evaluation work in the EU to support systematic evidence-
\end{abstract}

C. Haug $(\varangle)$ · D. Huitema · E. Massey · H. van Asselt · F. Berkhout Institute for Environmental Studies (IVM), Vrije Universiteit Amsterdam, De Boelelaan 1085, 1081 HV Amsterdam, The Netherlands

e-mail: constanze.haug@ivm.vu.nl

T. Rayner · A. Jordan

Tyndall Centre for Climate Change Research, University of East Anglia, Norwich, UK

S. Monni

European Commission, Joint Research Centre, Ispra, Italy

R. Hildingsson · J. Stripple

Department of Political Science, Lund University, Lund, Sweden 
based policy making. This reduces the scope for sound policy making in the short run and is a constraint to policy learning in the longer term.

\section{Introduction}

Climate change is now recognised as the most challenging environmental problem confronting humanity. This heightened political pressure has fed through to greater policy making activities in many jurisdictions, but especially the European Union (EU), which has proclaimed itself a global leader. ${ }^{1}$ Climate policy, aimed at preventing dangerous climate change and adapting to a range of impacts now recognised to be inevitable, has become a high political priority, indeed a raison d'etre, for the EU. However, governing climate change has proven to be very difficult. Governance, which we take to be a "purposive" and "goal-oriented" activity (Rosenau 1992, p. 4), requires policy makers to make difficult choices between alternative courses of action. These choices are usually made in a context of intense bargaining, which involves trading off values that may be incommensurate and potentially conflicting. Therefore, policy making often generates dilemmas (see Jordan et al. 2003), commonly defined as situations requiring selecting between equally unpleasant alternatives (e.g. Webster's New World Dictionary). In the context of governing, we have identified six dilemmas, which can be summarised as follows:

- Problem perception and policy objectives: How to frame the policy problem?

- Levels and scales of governance: At which level (or scale) of governance should one act?

- Timing and sequencing: How should the balance between a desire for predictability and the need for adaptiveness to changing circumstances be struck?

- Modes and instruments of governance: Which modes and instruments of governance are appropriate and effective?

- Costs and benefits: How should the costs and benefits of policies be distributed, and should losers be compensated?

- Implementation and enforcement: How should the preferred policy outcomes be secured?

In its White Paper on governance (CEC 2001), the EU explicitly committed itself to make choices and navigate dilemmas based as much as possible on evidence. This is also reflected in its pledge to pursue Better Regulation (Radaelli 2007). Many of the EU's Member States have made similar pledges to improve the evidence base of their governing activities (Nilsson et al. 2008). One potential key source of such evidence is studies evaluating the performance of previous policies (Weiss 1975, 1979). But to what extent do evaluations really provide insights and lessons-'evidence'-on which to base future policies? This paper addresses this question by looking at the content of evaluation studies conducted in the area of climate policy. It does so by reporting on the results of a meta-analysis of 262 climate policy evaluations conducted at the EU level and in six Member States since 1998. A meta-analysis is a widely accepted

\footnotetext{
1 "We can say to the rest of the world - Europe is taking the lead. You should join us in fighting climate change". European Commission President José Manuel Barroso at the Spring Council 8-9 March 2007. http://ec.europa.eu/energy/energy_policy/index_en.htm
} 
method initially developed in the medical community which aims at identifying dominant patterns in the results of multiple assessments-or, for us, evaluationsconducted in a particular policy field (e.g. Glass et al. 1981; Stufflebeam 2001). The evaluations in our meta-analysis were compiled from database searches, the internet, and 'snowballing' (i.e. asking different producers and users of evaluations-policy makers, evaluators and so on-for suggestions), in order to cover the widest possible range of studies. All of them are effectively in the public domain.

Our analysis is framed around the six governance dilemmas identified above. ${ }^{2}$ These dilemmas, we contend, should be adequately addressed in the evaluation studies if the latter are to serve as a valuable basis for policy making. We analyse the lessons-both for policy making and for future academic research-that flow from the patterns we observe. To be clear, our analysis limits itself to discussing the substantive content of the evaluations; we do not investigate the extent to which policy makers 'learned' from their conclusions. These are important questions that lie outside the scope of this article.

The remainder of this paper is structured as follows. The following section describes the methodology of the meta-analysis and the justification for choosing the seven case jurisdictions. Subsequently, Sections 3, 4, 5, 6, 7, and 8 discuss how the six governance dilemmas noted above were addressed in the 262 climate policy evaluations. Section 9 draws the different strands of the paper together, summarises the key findings and discusses the implications for future evaluation practice.

\section{Methodology}

Our extensive (although not exhaustive) research uncovered a long list of evaluations conducted since 1998. From this list, we identified studies that offered a systematic assessment of policies already in place (ex post evaluations), and excluded those that were either not sufficiently systematic (such as position papers by lobby groups) or that were wholly ex ante. Policies were classified as 'climate change' policies if they were reported as such in respective National Communications to the Secretariat of the United Nations Framework Convention on Climate Change (UNFCCC). ${ }^{3}$ This process resulted in a final dataset of 262 evaluation studies. The content and focus of each evaluation was coded according to a template comprising ten main criteria and 50 sub-criteria. ${ }^{4}$ One important consequence of our decision to concentrate on expost evaluations was a strong bias in our sample towards mitigation, with only seven

\footnotetext{
${ }^{2}$ For a similar list to the one presented here, see Bennett (1991). For an application to the politics of climate change, see Kok et al. (2002).

${ }^{3}$ All Parties to the UNFCCC are required to periodically submit National Communications to the UNFCCC Secretariat which contain information on emissions and removals of greenhouse gases in that country and on the activities the Party has undertaken to implement the Convention.

${ }^{4}$ The dataset is available at www.adamproject.eu. The cut-off date for our evaluations was March 2007. The main criteria ranged from the affiliation of the author(s) and main sector(s) addressed, to whether the evaluation was "technical-analytical" (accepting official policy goals as a given) or "discursive" (prepared to question official policy goals). In this way, we were able to develop an overview of the overall practice of climate policy evaluation in Europe (Huitema et al. 2008). The sub-criteria were derived from the six governance dilemmas.
} 
studies covering adaptation policies. This lack of attention in evaluations is not surprising, given that adaptation policies remain at such an early stage of development (Massey and Bergsma 2008).

Our sample of evaluations includes studies evaluating climate policies of the EU as a whole and of six of its Member States. In choosing these states we sought to reflect the social, political, economic, and geographical diversity of Europe (Fig. 1). We included two large northern European countries, the UK and Germany, both of which have tended to be drivers of the EU climate change policy agenda (Jordan and Liefferink 2004), have robust economies, and display a relatively high degree of public involvement in policy making. Two southern European countries, Portugal and Italy, are also covered by the analysis. While differing in size and economic conditions, they have similar geographic characteristics. Both can be characterized as 'followers' in the sphere of environmental policy agenda-setting and have seen less public debate about climate change (ibid). Finland, a small, rich and sociallyprogressive country represents the Scandinavian perspective and Poland represents the bloc of post-2004 Member States from Central and Eastern Europe. Finally, given the increasing importance of EU-level action, we also included evaluations covering the EU as a whole.

It is perhaps not surprising that in a multi-levelled, differentiated political space like the EU, the total evaluation effort is rather unevenly spread (see Fig. 1). The

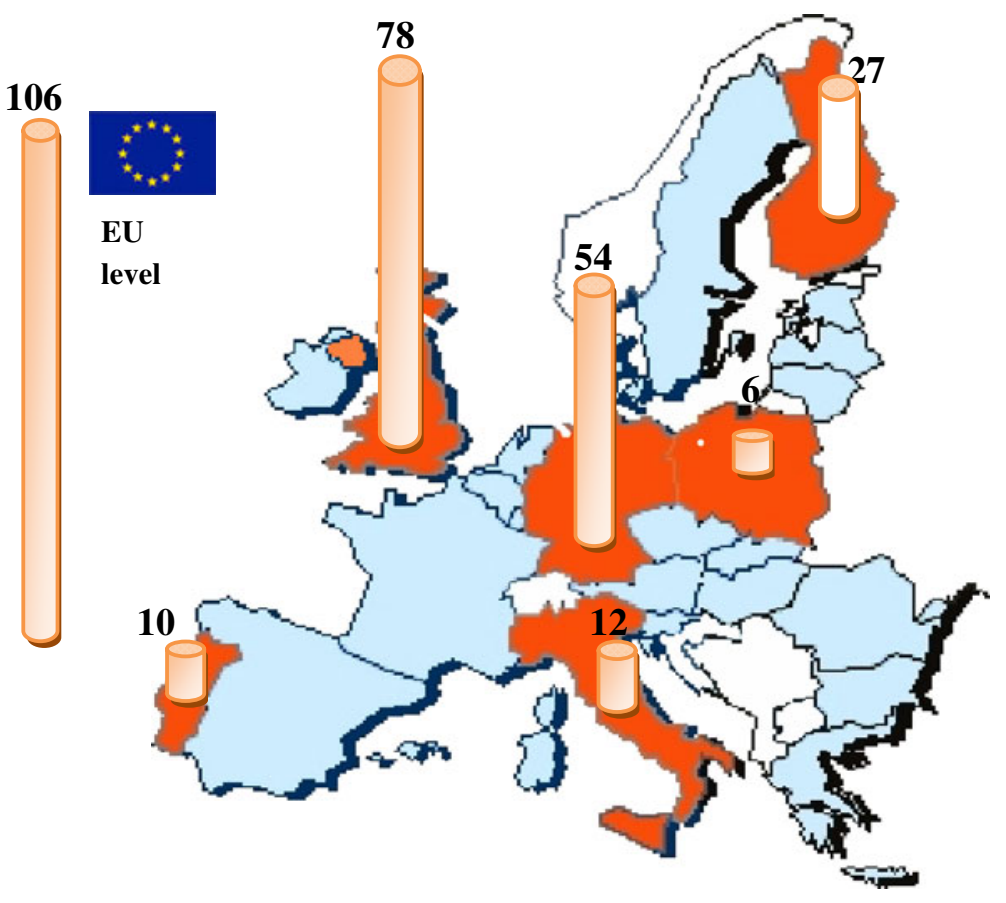

Fig. 1 EU Member States covered by the meta-analysis and number of evaluations retrieved per jurisdiction. Note for this graph, and also for Fig. 2 that reports were counted multiple times when they covered more than one case jurisdiction or applied more than one evaluation criterion 
bulk of the 262 evaluation studies that we were able to retrieve address climate policy in the UK (78 studies), Germany (54) and at the EU level (106 studies). By contrast, for Portugal and Poland we found only ten and six studies respectively, many of them prompted by EU directive reporting requirements. Finally, the majority (58\%) of the evaluations in our sample had not been commissioned by a government institution, suggesting a certain level of independence of the evaluators. Among the studies that were commissioned, $59 \%$ were solicited by governmental bodies (see Huitema et al. 2008). The following sections discuss how the evaluation studies address each of the six governance dilemmas identified above.

\section{Problem perception and policy objectives}

Problem perceptions and framing are fundamental to the handling of a policy problem (Majone 1989; Schön and Rein 1994). How a problem is perceived by governments and the public at large shapes decisions over whether policy is developed at all, what instruments are employed, when action is taken, at what administrative level that action is focused, and what financial and human resources will be devoted to it.

Few studies in our dataset address this dilemma explicitly-most stay close to what one might term the official climate policy discourse in the EU. Thus, almost all the studies we reviewed emphasise the urgency with which measures to cut greenhouse gas emissions need to be taken. A number of them support a higher degree of ambition with regard to the emission reduction targets that the EU and its Member States have set for themselves, including a stronger link of these objectives to the EU's $2^{\circ} \mathrm{C}$ target (e.g. FoEE 2005; Lechtenböhmer et al. 2005). Yet these criticisms relate more to 'tweaking' existing commitments than calling for a radical change in direction. Indeed, only $18 \%$ of the evaluations can be considered as 'discursive' or 'reflexive', by which we mean questioning the dominant framings of the climate problem-all the more surprising given the high number of independently conducted evaluation studies, as discussed above.

Two further themes emerge from the evaluations with regard to problem perception: the framing of climate change as a market failure and/or state failure, and the degree to which climate policy to date has been the product of a 'co-benefits' strategy. In the evaluations reviewed, the underlying diagnosis of the climate change problem is that it derives from a combination of market failure-the inadequate allocation of property rights and/or prevalence of unpriced external costs - and what might be labelled state failure - the lack of effort made to integrate environmental considerations into the day-to-day working of government. Hence, the strong implication of the bulk of evaluations is that climate change can in principle be adequately dealt with, even in the context of a continually growing economy, provided appropriate measures are taken to correct such failures (e.g. SRU 2004; Lechtenböhmer et al. 2005; Egenhofer et al. 2006b).

Framing the problem in this way leads to the promotion of market-based instruments to incorporate the wider 'social cost of carbon' (e.g. WBBWA 2004; OECD $2002 \mathrm{~b}$ ). The removal of perverse incentives in the form of subsidies to polluting activities, such as coal mining, is more prominent as a recommendation in many evaluations (e.g. SRU 2000; OECD 2001; Michaelowa 2003) than in everyday policy 
practice. Evaluations also note that several long-standing measures reported as climate policies were initially designed as responses to other problems. ${ }^{5}$ Evaluation studies vary in the extent to which they seek to quantify these co-benefits, but it is reported that their existence has helped policy makers in securing support for key policies (e.g. Szarka and Blühdorn 2006).

We conclude that climate policy evaluations do not, in general, challenge dominant framings of the policy problem as one of market and state failure with regard to greenhouse gas emissions. Only a small number of the more discursive studies argue that more radical problem framings are needed-such as a mitigation approach based on personal carbon budgets. The conservatism of most evaluations serves to further embed a dominant framing of the climate problem and the policy responses to itreducing emissions by pricing climate damages and implementing policy integration (Kuik et al. 2008). However, evaluations also acknowledge that there are often political obstacles to policy formation, and show that (unquantified) claims to cobenefits have frequently been necessary to justify policy action.

\section{Levels and scales of governance}

In the EU, the question of the appropriate level of policy action has been a foundational issue, especially sharply focused since the notion of 'subsidiarity' (that matters should be dealt with by the lowest or least centralised competent authority) entered into EU policy discourses in the early 1990s (Jordan 2000). The essential governance dilemma here is that, left to their own devices, Member States may not make sufficient headway to ensure that the EU meets its collective commitments; however, too much central steering could entail unacceptably high costs, turn out to be ineffective and meet strong political resistance from states concerned about economic competitiveness, as well as about losing their competence to the EU.

Questions regarding the relationship between the European dimension of policy making and national action are addressed in almost half (49\%) of the evaluations we reviewed. Interestingly, none of the studies refer to negative interactions between climate policies at the EU and Member States levels, although Agnolucci (2006), for example, notes how uncertainty over a draft EU directive stifled renewables growth in Germany for a period. ${ }^{6}$ On the contrary, evaluators' support for greater

\footnotetext{
${ }^{5}$ For example, the first renewables support programmes in the 1970s were adopted largely as a response to the oil crisis and resulting security of supply concerns (Wustenhagen and Bilharz 2006). Equally, pollution standards for both stationary and mobile sources across the Community were in many cases imposed mainly with the primary purpose to tackle local air pollution, with reduced greenhouse gas emissions as a welcome side-effect (e.g. OECD 2003).

${ }^{6}$ The ETS has also given rise to concerns that it would effectively make redundant significant parts of national climate change programmes (Sorrell and Sijm 2003). It is possible that the reason such clashes are not being identified is that evaluators are choosing not to address this issue. Interestingly, however, where one potential clash was identified-between the ETS and the Declaration by German Industry on Global Warming Prevention - the incompatibility was resolved by partly basing the first National Allocation Plan on the targets adopted in the declaration.
} 
harmonisation at the EU level appeared strong across our dataset, especially with regard to the European emissions trading scheme (EU ETS) and carbon taxation. The initial design of the EU ETS in 2003 left many important decisions to the discretion of Member States, including the determination of the total quantity of allowances to allocate, and the distribution of allowances between sectors and installations (Grubb et al. 2005). These issues were to some extent addressed in the 2008 revision of the Emissions Trading Directive (2008/101/EC).

Another area considered a candidate for increased harmonisation by a number of evaluations was energy policy, more specifically taxation and the promotion of renewables. Although efforts to introduce a European-level carbon tax failed in the early 1990s, calls for harmonisation are still a recurrent theme in policy evaluations (Prime Minister's Office, Economic Council 2000; Interwies et al. 2002). For the most part, however, they remain at a fairly general level, emphasising the economic efficiency advantages of a uniform European tax over a patchwork of national schemes, while acknowledging the political obstacles to tax harmonisation, and without going into much detail regarding design and implementation.

Perhaps most interesting are the findings regarding the relationship between the EU's climate measures-so-called Common and Co-ordinated Policies and Measures (CCPMs) - and those of its Member States. At issue here is how a balance is struck between the need for coordination and the desire for flexibility at the national and local level. Relatively few studies (seven in total) considered the relation between CCPMs and national policies. Most of these were either commissioned or written by the European Commission and/or the European Environmental Agency. One of the reasons for this relative scarcity may be that Member State evaluation studies do not refer to CCPMs directly, even though national policy often finds its origin in these coordinated policies. The studies that do highlight the relationship assert that CCPMs often work as drivers for national mitigation action, especially in cases where the Member State has not been active in the field before (e.g. Golder Europe EEIG 2005; EEA 2006; CEC 2007a). The quantitative targets of many CCPMs, as well as the reporting obligation, support their effectiveness-even if not all Member States comply fully with the targets set. With regard to national policies of the European 'leaders', there is little evidence in the evaluations that 'Europeanisation' has hindered or reduced the innovativeness or effectiveness of national action.

In sum., a majority of evaluation studies in our sample provide evidence that the harmonisation of climate policies at EU level is beneficial. Calls for more centralised steering refer most often to the EU ETS and to aspects of energy policies, especially taxation and renewables promotion. The studies also demonstrate the benefits of CCPMs as effective means to diffuse climate policies to 'laggard' Member States while not limiting the freedom of 'leader' countries to implement more ambitious policies.

\section{Timing and sequencing}

The timing and sequencing dilemma encompasses a range of questions, concerning whether to act early or postpone action, the timescale over which policy should be introduced, and the dangers of becoming 'locked in' to inappropriate policy 
pathways (Pierson 2000). In an area like climate policy that is characterised by long time horizons and great uncertainty over potential costs and benefits of different courses of action, some reflections on the merits of flexible 'adaptive governance' (e.g. Huitema et al. 2009) against long-term regulatory stability might be expected to show up in policy evaluations.

Overall, the attention given to the timing and sequencing dilemma was most explicit in the evaluations addressing two policy domains: the EU ETS and the diffusion of renewables. Concerning the EU ETS, the dilemma is most salient with regard to the length of the trading periods. Several evaluations considered their relatively short duration (5 years in the period up to 2012, and 7 years after that) a significant drawback (Egenhofer et al. 2006a). The ability of Member State governments to go 'back to the drawing board' prior to each new allocation period implies that certainty can only be provided for up to five years ahead (ibid). Longer trading periods would provide greater predictability, reducing investment risks.

With respect to renewable energy, the evaluations in our data set identified continuous political support and policy stability as key conditions for enabling growth and diffusion (CEC 2005). Moreover, the design of the mechanism chosen for the promotion of renewables, in particular its influence on the level of risk for renewable energy investors, emerged as crucial (CEC 2005; Jacobsson and Lauber 2006). Based on the evaluations we reviewed, feed-in laws to stimulate renewable energy sources (used for example in Germany and Portugal) seem to have fared better in this regard than green certificate schemes (e.g. Mitchell et al. 2006; Szarka and Blühdorn 2006). The greater investment certainty under a feed-in scheme stems from the fact that the price paid for renewable energy is stable: producers bear no 'volume risk' because network distributors are required to accept all generated green energy. By contrast, under a certificate scheme (such as the Renewables Obligation in the UK), the value of the certificates is much less predictable since it depends on supply and demand in the market (Mitchell et al. 2006). This additional economic uncertainty on top of other technical and regulatory uncertainties is widely perceived as a critical obstacle to renewable investments, borne out by the much more rapid expansion of renewables in countries with feed-in tariffs.

The available evaluation studies also suggest that there need not necessarily be a trade-off between predictability and adaptiveness in renewables policy, provided that the support mechanism in place is well designed. The German system of feed-in tariffs, for instance, while creating a more stable investment climate than the UK's tradable green certificates system, also seems to be more flexible, due to regular reviews built into the instrument (Szarka and Blühdorn 2006).

To conclude, the evaluations in our sample tend to confirm the 'early action' mitigation strategy which, at least rhetorically, has been at the core of the EU's political position on climate change since the late 1980s. Timing and sequencing considerations have influenced policy design especially in debates about the EU ETS and renewable policy, both of which have sought to balance predictability of a policy against its adaptiveness. On renewables, the German experience suggests that an emphasis on predictability need not compromise flexibility. In the case of the ETS, the main concern has been with the length of allocation periods. However, this may have become less pressing as the general political commitment to climate policy has grown within the EU since 2005, thereby reassuring would-be investors of the economic wisdom of investing in emissions reductions. 


\section{Modes and instruments}

A recurrent dilemma in environmental policy making is how far to rely on hierarchical, market or network-based modes and instruments of governance respectively (Jordan et al. 2003). The main challenge confronting policy makers is how to choose modes (and their associated policy instruments) in a way that maximises their strengths and reduces their weaknesses. This implies dilemmas related to how to strike the balance between hierarchical authority and market autonomy in policy design.

Across our dataset, considerable attention was dedicated to the evaluation of voluntary agreements (Table 1). Studies tend to agree that voluntary action such as the Declaration of German Industry on Global Warming Prevention, an example of a unilateral industrial commitment at least in its initial versions, has largely failed in stimulating significant emission cuts. In the German case, many of the targets have been set close to business-as-usual projections, implying that most reductions would have taken place irrespective of the declaration (Krarup and Ramesohl 2000; SRU 2000; RWI 2000). Similar findings apply for the UK Climate Change Agreements (CCAs) from 2001. Despite showing a high degree of participation, the effectiveness of the agreements is contested by a number of studies (e.g. EAC 2004; Glachant and de Muizon 2007). Most sectors exceeded their quantitative targets for 2010 well in advance of the official deadline, without requiring special effort (FES 2005).

More positive conclusions on the effectiveness of voluntary agreements can be drawn from the Finnish experience. Based on the studies we reviewed, the Finnish Energy Conservation Agreement scheme seems to demonstrate that (public) voluntary programmes can be successful in stimulating participation and energy saving measures, provided they are accompanied by proper incentives (in this case government subsidies for energy auditing and energy saving investments) (Heikkilä et al. 2005; Pöllänen and Kalenoja 2005). The energy and climate objectives of the programme are projected to be exceeded (Motiva 2006). However, the schemes seem mainly to collect 'low hanging fruits'; most implemented measures have a relatively short payback time (Khan 2006).

In sum, the meta-analysis confirmed the widely-held view that voluntary agreements are unable to bring about far-reaching changes in behaviour by firms and sectors. Most studies explain the disappointing performance of voluntary agreements by citing unambitious targets and the lack of incentives for participation and compliance mechanisms. Finally, hardly any evaluations have attempted comparisons be-

Table 1 Frequently evaluated voluntary agreements

\begin{tabular}{lc}
\hline Type of voluntary agreement & Example of voluntary agreements assessed \\
\hline $\begin{array}{l}\text { Unilateral agreements by industrial firms } \\
\text { (i.e. self-commitment) }\end{array}$ & Declaration of German Industry on \\
Public voluntary schemes & Global Warming (DGWP) \\
& Finnish Energy Conservation Agreement \\
Negotiated agreements & Scheme (incl. Energy Audit Programme) \\
& UK Climate Change Agreements (CCAs); \\
& ACEA-JAMA-KAMA (car manufacturing) \\
& covenants \\
\hline
\end{tabular}

Typology based on Börkey and Lévèque (1998) 
tween different instruments, an unexpected omission given that the choice between instruments typically generates significant policy dilemmas in the governance process (Linder and Peters 1989).

\section{Costs and benefits}

When deciding when, at which level, and by what means to act, policy makers also have to weigh the associated costs and benefits. Although policy interventions may seek to generate net social benefits, they inevitably generate winners and losers (Bennett 1991). The most important governance dilemma in this context is what costs and benefits to take into account and whether any losers will be compensated. Judgements on these issues are tied to considerations about policy effectiveness, fairness, legitimacy and the relative power of affected parties.

The issue of distributive equity in climate policy is not widely covered in the evaluation studies we reviewed. Only a small number used fairness (which we take to mean equity in the sharing of costs and benefits between actors) as an evaluation criterion (see Fig. 2). This lack of attention may, if Weidner (2005) is correct, reflect a degree of political expediency, whereby governments prefer not to highlight the regressive nature of many of their policies.

Amongst our sample of six Member States, official UK evaluations did the most to record the distribution of costs and benefits, recording how they affected three groups: the Treasury, firms and consumers. Yet judgments about where the burden

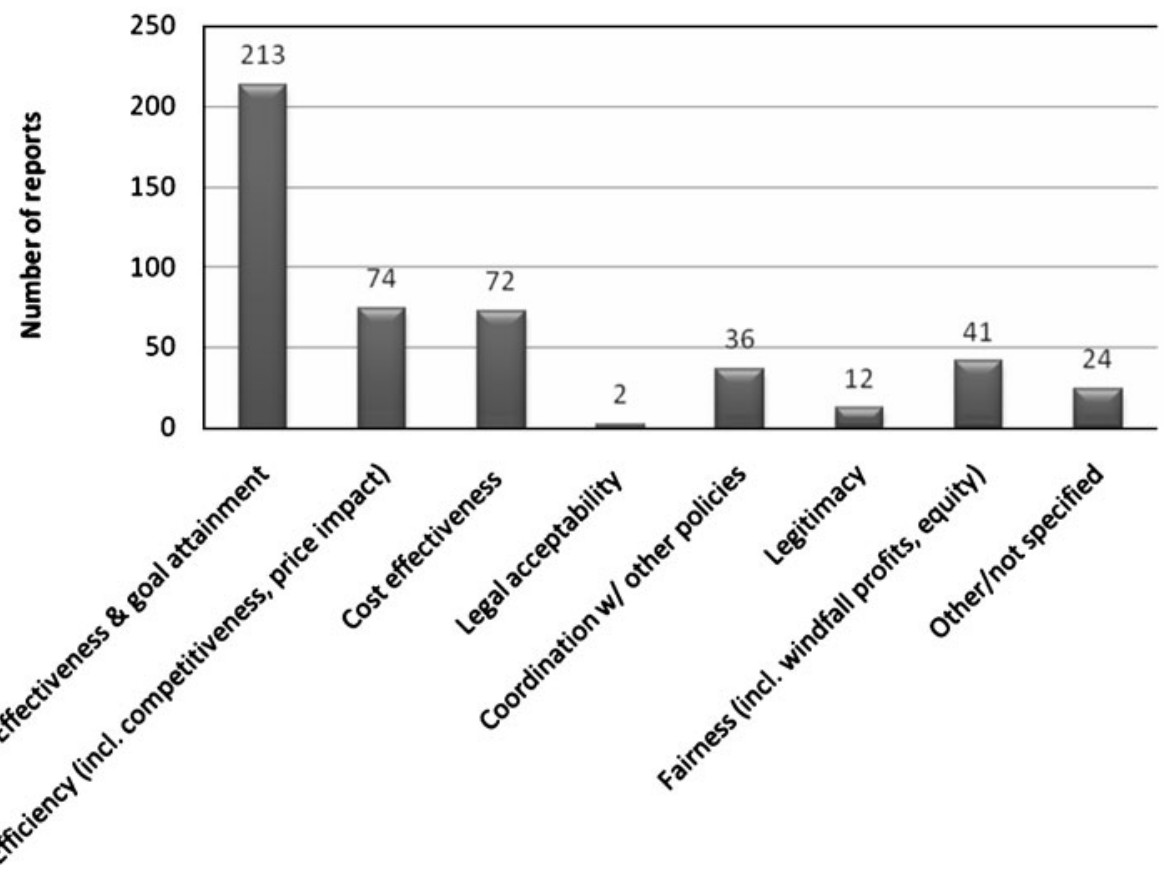

Fig. 2 Criteria used in the evaluations 
ultimately falls are complicated by uncertainty over the extent to which additional costs incurred by firms are passed on to consumers. Economic models suggest that this is likely to be the case for between $50 \%$ and $100 \%$ of any cost increases, depending on the competitiveness constraints faced by businesses (DEFRA 2006).

Where distributional and equity concerns are prominently discussed is in the growing number of evaluations of the consequences (particularly for households) of carbon-energy taxation and EU emissions trading. The reason for this greater attention appears to be that while the costs associated with established regulatory instruments tend to remain hidden from the general public, potential changes to the status quo following the introduction of new carbon taxes and emissions trading are more politically controversial (see Bressers and Huitema 1999).

Along with competitiveness concerns, the distributional implications of carbon taxes are a major issue in determining their political acceptability. Evidence from the evaluations suggests that carbon taxes may be mildly regressive (because lower income groups spend proportionately more of their income on energy-related expenditures), but this often depends on the modelling framework used (e.g. Tiezzi 2005). However, this regressive effect can be greatly reduced, or even reversed, where the tax is applied in a revenue-neutral context. This varies across Member States. Symons et al. (2002) find that while energy or $\mathrm{CO}_{2}$ taxation is regressive in Finland, Germany, France and, to a lesser degree, in Spain, it is progressive in the UK (except for the highest income group) and neutral in Italy. Moreover, regional distributions are uneven, with households in rural areas being disproportionately affected (Mustonen and Sinko 2000).

In handling the revenues from carbon taxation, a key trade-off emerges between efficiency and equity. Interestingly, this dilemma is treated differently in different Member States. Where a part of the revenues is used to compensate poorer households suffering from an increased tax burden, the scope for the revenues to be used to maximise the efficiency gains from reductions in other existing distortionary taxes, for example Value Added Tax (VAT), will be lost. In Germany, for example, the ecological tax reform recycled tax revenues by cutting employers' and employees' social security contributions in equal measure, showing less concern "with fiscal orthodoxy and more with political appeal" (Andersen et al. 2007, p. 523).

Debates about efficiency (the functioning of the market and its ability to achieve environmental benefits) and equity (redistribution of wealth) have also been prominent in the context of the evaluations of the EU ETS. The generous allocation of emissions allowances to installations covered by the scheme has shifted the burden for achieving Europe's Kyoto targets to the non-emissions trading sectors (Rogge et al. 2006). ${ }^{7}$ Moreover, the ETS has led to an increase in electricity prices in the EU (Sijm et al. 2006), with power producers able to pass on costs to their customers, both industrial and household, giving them windfall profits. This could have adverse consequences for industries falling both within and outside the scope

\footnotetext{
${ }^{7}$ The EU ETS covers large emitters in the power and heat generation industry and in selected energyintensive industrial sectors. Key emitters outside the EU ETS are the transport and domestic sectors. For the period 2012-2020, however, the burden sharing between the sectors has changed-under the new EU climate and energy package, the EU ETS is expected to reduce emissions by $21 \%$ by 2020 compared to a 2005 baseline, the other sectors by $10 \%$ (COM (2008)30).
} 
of the ETS (see e.g. Egenhofer et al. 2005; Sijm et al. 2006; Neuhoff et al. 2006; Legambiente 2007).

In summary, the degree to which explicit attention is dedicated to the costs and benefits of governing (here narrowly interpreted as distributive equity) varies across our dataset of evaluations. Equity is examined most thoroughly with regard to the EU ETS and carbon taxation, highly visible and relatively controversial policy instruments. The evaluation studies in our sample indicate that effective climate policies involving carbon taxation tend to be mildly regressive, but the different experiences across countries suggest this is by no means inevitable. In the case of the ETS, certain powerful sectors of industry appear to be able to pass the burden of emission reductions to politically less influential groups, namely household consumers.

\section{Implementation and enforcement}

Implementation is the part of the policy process in which the chosen instruments are applied to a target group, their response monitored, and any deviations from the expected outcome responded to. The key dilemma here relates to whether provisions should exist for sanctions against non-compliance and what level of monitoring and enforcement is desirable.

The vast majority of the evaluations we reviewed (roughly 67\%) devoted considerable attention to the state of implementation and enforcement of climate policies. Overall, the idea of an 'implementation gap' in EU environmental policy (Jordan 1999), long prominent in European policy circles, is reinforced. Thus, a number of EU-level evaluations express concern at the incomplete implementation of the measures outlined in the European Climate Change Programme (CEC 2006a) referring, variously, to the chain of procedures including political adoption of the proposed policies by EU institutions, transposition into Member State law, enforcement by national authorities, and recourse to European-level sanctions in case of non-compliance (e.g. CEC 2006b, c, 2007b).

Three further themes relating to implementation and enforcement emerge from the meta-analysis: loopholes in the design of some instruments; poor provisions made for monitoring; and the weakness or indeed lack of enforcement mechanisms for many policies. Starting with the first of these, many evaluations demonstrate that policy instruments that were initially designed with some degree of ambition are watered down before their implementation. The reason for such last-minute modification is often the same: the need to secure support from influential lobbies that would otherwise block the policy from being adopted. The many special rules and exemptions from energy taxation, for instance in Italy and in Germany, are one example for this (OECD 2002a; Böhringer and Schwager 2003).

Moving on to monitoring, ex-ante and ex-post measurements of the performance of policy instruments are undoubtedly a precondition to establishing their effectiveness and for learning from implementation experience (Sabatier 1986). Thus, one particularly striking theme to emerge from the meta-analysis was the widespread condemnation of the poor provision for monitoring that characterises many policy instruments (e.g. EAC 2005b; Maslin et al. 2007; RWI 2000). In their attempts to evaluate the effectiveness of 20 energy efficiency policies, Ecofys et al. (2007) were 
hampered by the fact that most instruments lacked a comprehensive monitoring system. Even though methodologies are widely known, both the availability and quality of monitoring data for the impacts of specific policy instruments turned out to be much lower than expected. ${ }^{8}$ To take the example of the ETS, lack of reliable ex-ante data at the installation level was a source of difficulties in determining the cap and distribution of allowances in the first phase of the EU ETS (Ellerman and Buchner 2006).

A broader issue that is frequently raised in the evaluations in our sample is the lack of early-warning mechanisms to inform policy makers about whether policies will deliver the intended results. On this question, it is instructive to note that even in a country with a relatively mature climate policy such as the UK, a leading watchdog criticized the time taken by the government to acknowledge that the policy was "so far off course" (EAC 2005a, p. 40) from its 2010 targets, due to inadequate monitoring. On top of this, policymakers are faced with the possibility that apparent successes may in fact be less significant than supposed, owing to 'rebound effects', i.e. energy savings due to efficiency improvements being offset by increased consumption (DEFRA 2006; Maslin et al. 2007). Evaluations in our sample often acknowledged the need for more sophisticated monitoring of such effects and treatment in calculations of emission reductions obtained (e.g. FES and PSI 2005).

Another frequently highlighted concern is the paucity of enforcement mechanisms (e.g. IPA Energy and Water Consulting 2007; SRU 2005; Maslin et al. 2007). This is particularly pertinent in the case of voluntary agreements (RWI 2000), but also in green certificate schemes, Poland being one example (CEC 2007b). Furthermore, non-compliance is a cause of concern in the building sector, where energy standards for new buildings are often poorly enforced (see e.g. Maslin et al. 2007; Oxera 2005), apparently due to concerns over the impact on property developers.

In conclusion, the most striking theme to emerge from the meta-analysis is the generally poor provision made for monitoring that characterizes many policy instruments. Many evaluations conclude with strong recommendations that future policies be fully implemented and equipped with adequate monitoring and enforcement mechanisms.

\section{Conclusions}

In this paper, we have reviewed the potential stock of usable evidence on the evolution and performance of European climate policies, based on a meta-analysis of 262 evaluation studies. Our analysis was organised around six governance dilemmas that policy makers commonly encounter when developing new policy interventions or when deciding how to improve existing ones. In a broad sense, the evidence the evaluations generate is quite extensive. For example, all six governance dilemmas were addressed in the evaluations we reviewed. However, they did not engage with all dilemmas to the same extent.

The issue of problem perception, for example, was certainly much more implicit in the studies than the other dilemmas. Evaluators for the most part seem to accept

${ }^{8}$ This report was not included in our sample of evaluations since it was published after the cut-off date for the meta-analysis (March 2007). 
the problem framings inherent to the policy measures they are evaluating. Levels and scale dilemmas were analysed at length in only a relatively small number of evaluations, suggesting either consensus about the proper roles for European and national action, or the need for more debate. With regard to timing and sequencing, the evaluations in our database addressed the predictability of policy measures, while neglecting the critical issue of the sequencing of policies. On the selection of modes and instruments of governance, in many of the evaluations we noted a preference for more regulatory modes of governance, mainly in response to the perceived difficulty of adopting fiscal measures and the apparent ineffectiveness of voluntary approaches. Given the political prominence of the EU's focus on Better Regulation, regulatory simplification and lessening regulatory burdens, we expected to find many more explicit cost-benefit analyses of policy instruments. Yet, only $4 \%$ of the studies reviewed were based on cost-benefit analyses or related methodologies. The discussions of distributive equity were largely limited to the impacts of two highly visible policy instruments: taxes and emissions trading. Finally, issues to do with implementation and enforcement were the focus of a large part of the evaluations, which identified loopholes in many policies and criticized poor monitoring of many policy instruments.

Given this broad-but uneven-spread, do existing evaluations allow us to draw firm conclusions regarding the effectiveness of European climate policies? Although the majority of the evaluation studies we reviewed were concerned with the effectiveness (or goal attainment) of policies (see Fig. 2), few clear-cut lessons emerge. In part, this is related to the limited amount of quantitative assessment in current climate policy evaluation: most of the studies in our sample did not contain an explicit 'tonnes per policy' analysis of the contribution of specific policies to attaining the goal of emissions reduction. Such quantification was most common in UK assessments (included in roughly a third of the UK studies), but much less common in the other jurisdictions. Even where such assessments were included, a variety of techniques was used, often generating divergent results. The span of opinion on the effectiveness of European climate policy ranges from Eichhammer et al. (2001, p. 1), who assert that in the UK and Germany, "a mix of policies at the national and regional levels added considerably to the reduction of greenhouse gases", to Kerr (2007), who argues that there is no statistically significant data to show that climate policies have produced an effect.

The relatively small number of 'tonnes per policy' assessments and the variability of the results could have a number of causes. Often no baseline scenario for emissions was established before a policy was initiated. This makes it difficult to construct the counter-factual, i.e. what would have happened in the absence of a policy measure. A further problem is that quantitative data on emissions and other 'non-policy' factors that might explain changes may not be available yet because monitoring programmes have not been in place long enough. Besides these problems, which might be termed operational, there is also the analytical problem of attribution. Emissions are continually and dynamically influenced by a wide range of economic, technical and other factors. There will also be a range of policy measures that influence them, directly or indirectly. European policies to create competitive and liberalised energy markets have had a clear downward impact on energy prices, which would tend to lead to increased consumption and, assuming a static energy supply system, rising 
greenhouse gas emissions. EU and Member State climate policies seek to produce the opposite effect.

But such policy interactions also occur between different climate policies, both within and between European jurisdictions. Climate policies are often framed as policy packages (the 2008 EU Climate and Energy Package continues this pattern). Separating the signal of these packages of measures, let alone that of an individual policy, from the 'noise' of the many other factors that influence emissions remains an extremely difficult exercise. This is especially the case if the data to conduct a good decomposition analysis, a baseline to use as a counter-factual, does not exist. We remain sceptical about whether it will ever be possible to produce an analysis of the performance of climate policy measures that wins universal agreement. After all, evaluation is, “... an activity which is knee deep in values, beliefs, party politics and ideology, and this makes proving that this policy had this or that impact a notion which is deeply suspect" (Parsons 1995, p. 550).

By examining the content of 262 climate policy evaluations, this paper has, however, generated a far better survey of the 'supply side' of evaluation-the stock of potentially usable evidence available to policy makers-than appears in the existing literature. Yet, even if the coverage and quality of evaluations was adequate (and as discussed above, this is unfortunately not the case so far in the EU), their impact on policy making is, the literature also informs us, still far from assured (Weiss 1975; Nilsson et al. 2008). Producing good evaluations is one thing, but getting policy makers to draw upon them is something altogether different. Future research could therefore benefit from more focus on the interface between evaluation and its uptake in policy making, thus moving closer to the 'demand side' of climate policy evaluation. Some related questions are explored in a companion paper (Huitema et al. 2008), which discusses trends in current evaluation practice in Europe based on the same dataset as the present analysis. Yet further investigation into possible mismatches between the 'supply' and the 'demand side' and the question of how policy makers can learn from the evidence provided by policy evaluations is definitely warranted (Nilsson et al. 2008; Nutley et al. 2007).

Be that as it may, with the 2008 EU Climate and Energy Package, EU climate policy arguably entered a new and more vigorous phase. If the EU wants to continue its global political leadership in the climate arena it needs to demonstrate that it can bring down its greenhouse gas emissions while securing economic welfare for European industries and citizens. Knowing whether and how climate policies work is essential to achieving these goals. At present we know too little about how European and Member State policies influence greenhouse emissions, to a large extent because the evidence base for conducting good policy evaluations is lacking. There is an urgent need for a more uniform framework for evaluating climate policies (singly and as packages) ex-ante, to collect data relevant to ex-post evaluations and to permit independent bodies to conduct such evaluations at regular intervals. Armed with this information, policy makers would be in a better position to re-design existing policies both 'smartly' (Gunningham and Gabrosky 1998) and adaptively.

Acknowledgements The research was conducted under the auspices of the project Adaptation and Mitigation Strategies (ADAM), financed by DG Research of the European Commission. The authors would like to thank Agnieszka Markowska, Ana Horga, and Jacopo Baggio for research 
assistance. Joachim Schleich, Diana Reckien, Maartjan Schelhaas, Benjamin Pohl as well as two anonymous reviewers helpfully provided thoughtful comments on earlier drafts. This work also benefited significantly from the stimulating discussions at the ADAM-funded workshop "Evaluating European Climate Policy" held in Brussels in January 2008.

Open Access This article is distributed under the terms of the Creative Commons Attribution Noncommercial License which permits any noncommercial use, distribution, and reproduction in any medium, provided the original author(s) and source are credited.

\section{References}

Agnolucci P (2006) Use of economic instruments in the German renewable electricity policy. Energy Policy 18:3538-3548

Andersen MS, Barker T, Christie E et al (2007) Competitiveness effects of environmental tax reforms (COMETR) National Environmental Research Institute. University of Aarhus, Aarhus

Bennett G (1991) Dilemmas: coping with environmental problems. Earthscan, London

Böhringer C, Schwager R (2003) Die Ökologische Steuerreform in Deutschland—ein umweltpolitisches Feigenblatt. PWP 4:211-222

Börkey P, Lévèque F (1998) Voluntary approaches for environmental protection in the EU. OECD, Paris

Bressers JTA, Huitema D (1999) Economic instruments for environmental protection. Can we trust the magic carpet? Int. Polit. Sci. Rev. 20:175-196

CEC (2001) European governance. A white paper. CEC, Brussels

Commission of the European Communities (CEC) (2005) Communication from the commission: the support of electricity from renewable energy sources. CEC, Brussels

CEC (2006a) The European climate change programme. EU action against climate change. CEC, Brussels

CEC (2006b) The second European climate change programme. Working group ECCP reviewtopic group energy supply. Final report. CEC, Brussels

CEC (2006c) The second European climate change programme. Working group ECCP reviewTransport. Final report. CEC, Brussels

CEC (2007a) Biofuels Progress Report. Report on the progress made in the use of biofuels and other renewable fuels in the Member States of the European Union. CEC, Brussels

CEC (2007b) Green Paper follow-up action: report on progress in renewable electricity. Communication from the Commission to the Council and the European Parliament. CEC, Brussels

Department for Environment, Food and Rural Aff airs (DEFRA) (2006) Synthesis of climate change policy evaluations. DEFRA, London

EAC (House of Commons Environmental Audit Committee) (2004) Budget 2004 and energy. The Stationary Office (TSO), London

EAC (2005a) Pre-budget 2004 and budget 2005: tax, appraisal, and the environment. TSO, London

EAC (2005b) The international challenge of climate change: UK leadership in the G8 and EU. TSO, London

Ecofys, Lund University, Wuppertal Institute for Climate, Environment and Energy, Politecnico di Milano (2007) From theory based policy evaluation to SMART policy design. Ecofys, Utrecht

EEA (2006) Greenhouse gas emission trends and projections in Europe 2006. EEA, Copenhagen

Egenhofer C, Fujiwara N, Gialoglou K (2005) Business consequences of the EU emissions trading scheme. Centre for European Policy Studies (CEPS), Brussels

Egenhofer C, Fujiwara N, Åhman M et al (2006a) The EU emissions trading scheme: taking stock and looking forward. CEPS, Brussels

Egenhofer C, Jansen JC, Bakker SJA et al (2006b) Revisiting EU policy options for tackling climate change: a social cost-benefit analysis of GHG emissions reductions strategies. CEPS, Brussels 
Eichhammer W, Boede U, Gagelmann F et al (2001) Greenhouse gas reductions in Germany and the UK - coincidence or policy induced? Fraunhofer Institute for Systems and Innovation Research, Karlsruhe

Ellerman D, Buchner B (2006) Over-allocation or abatement? A preliminary analysis of the EU ETS based on the 2005 emissions data. Fondazione Eni Enrico Mattei, Venice

FES and Policy Studies Institute (PSI) (2005) Evaluation of the government's energy efficiency policies and programmes. AEA Technologies, Didcot

Friends of the Earth Europe (FoEE) (2005) How the European Union responds to the global threat of climate change. FoEE, Brussels

Future Energy Solutions (FES) (2005) Climate change agreements-results of the second target period assessment. AEA Technology/DEFRA, Didcot

Glachant M, de Muizon G (2007) Climate change agreements in the UK: a successful policy experience? In: Morgenstern RD, Pizer WA (eds) Reality check: the nature and performance of voluntary environmental programs in the United States, Europe, and Japan. RFF, Washington

Glass GV, McGaw B, Smith ML (1981) Meta analysis in social research. Sage, Beverly Hills

Golder Europe EEIG (2005) Report on implementation of the landfill directive in the 15 Member States of the European Union. Golder Europe EEIG, Berkshire

Grubb M, Azar C, Persson M (2005) Allowance allocation in the European emissions trading system: a commentary. Clim Policy 5:127-136

Gunningham N, Gabrosky P (1998) Smart regulation. Clarendon, Oxford

Heikkilä I, Pekkonen J, Reinikainen E et al (2005) Energiansäästösopimusten kokonaisarviointi. Finnish Ministry of Trade and Industry, Helsinki

Huitema D, Rayner T, Massey E et al (2008) Climate change policy evaluation across Europe. ADAM P2 deliverable. Available at www.adamproject.eu

Huitema D, Mostert E, Egas W et al (2009) Adaptive water governance: assessing the institutional prescriptions of adaptive (co-)management from a governance perspective and defining a research agenda. Ecol Soc 14:26

Interwies E, Blobel D, ten Brink R et al (2002) Ökosteuer-Stand der Diskussion und der Gesetzgebung in Deutschland, auf der EU-Ebene und in den anderen europäischen Staaten. Ecologic, Berlin

IPA Energy and Water Consulting (2007) UK power sector emissions-targets or reality. IPA Energy and Water Consulting, Edinburgh

Jacobsson S, Lauber V (2006) The politics and policy of energy system transformation. Energy Policy 34:256-276

Jordan AJ (1999) The implementation of EU environmental policy: a policy problem without a political solution? Environ Plann C 17:69-90

Jordan AJ (2000) The politics of multilevel environmental governance: subsidiarity and environmental policy in the European Union. Environ Plann A 32:1307-1324

Jordan A, Liefferink D (eds) (2004) Environmental policy in Europe. Routledge, London

Jordan A, Wurzel RKW, Zito AR (eds) (2003) 'New' instruments of environmental governance? Cass, London

Kerr A (2007) Serendipity is not a strategy: the impact of national climate programmes on greenhouse-gas emissions. Area 39:418-430

Khan J (2006) Evaluation of the energy audit programme in Finland within the framework of the AID-EE project. Lund University, Lund

Kok MTJ, Vermeulen W, Faaij A et al (eds) (2002) Global warming and social innovation. Earthscan, London

Krarup S, Ramesohl S (2000) Voluntary agreements in energy policy-implementation and efficiency. Wuppertal Institute for Climate, Environment and Energy, Wuppertal

Kuik O, Aerts J, Berkhout F et al (2008) Post-2012 climate policy dilemmas. Clim Policy 8: 317-336

Lechtenböhmer S, Grimm V, Mitze D et al (2005) Target 2020: policies and measures to reduce Greenhouse gas emissions in the EU. Wuppertal Institute and Wissenschaftszentrum NordrheinWestfalen, Wuppertal

Legambiente (2007) Stop al carbone per salvare il pianeta. Dal via libera del pna a riconversioni e nuove centrali agli incentivi CIP6 per il sulcis. Legambiente, Rome

Linder SH, Peters BG (1989) Instruments of government: perceptions and contexts. J Public Policy 9:35-38

Majone G (1989) Evidence, argument and persuasion in the policy process. Yale University Press, New Haven 
Maslin M, Austin P, Dickson A et al (2007) Audit of UK greenhouse gas emissions to 2020. UCL Environment Institute, London

Massey E, Bergsma E (2008) Assessing adaptation in 29 European countries. Instituut voor Milieuvraagstukken (IVM), Vrije Universiteit, Amsterdam

Michaelowa A (2003) Germany. A pioneer on earthen feet? Clim Policy 1:31-43

Mitchell C, Bauknecht D, Connor PM (2006) Effectiveness through risk reduction: a comparison of the renewable obligation in England and Wales and the feed-in system in Germany. Energy Policy 3:297-305

Motiva (2006) Energy conservation agreements-progress review 2005. Motiva Oy, Helsinki

Mustonen E, Sinko P (2000) Hiilidioksidiveron vaikutus kotitalouksien tulonjakoon. Government Institute for Economic Research, Helsinki

Neuhoff K, Åhman M, Betz R et al (2006) Implications of announced phase II national allocation plans for the EU ETS. Clim Policy 6:411-422

Nilsson M, Jordan A, Turnpenny J, Hertin J, Nykvist B, Russel D (2008) The use and non-use of policy appraisal tools in public policy making: an analysis of three European countries and the European Union. Pol Sci 41:335-355

Nutley SM, Walter I, Davies HTO (2007) Using evidence: how research can inform public services. Policy Press, Bristol

Organisation for Economic Co-operation and Development (OECD) (2001) Environmental performance review: Germany. OECD, Paris

OECD (2002a) Environmental performance review: Italy. OECD, Paris

OECD (2002b) Environmental performance review: United Kingdom. OECD, Paris

OECD (2003) Environmental performance review: Poland. OECD, Paris

Oxera (2005) Policies for energy efficiency in the UK household sector. Oxera, London

Parsons W (1995) Public policy: an introduction to the theory and practice of policy analysis. Edward Elgar, Aldershot

Pierson P (2000) Not just what, but when: timing and sequence in political processes. Stud Am Polit Dev 14:72-92

Pöllänen M, Kalenoja H (2005) Linja-autoalan energiansäästösopimuksen arviointi. Finnish Ministry of Trade and Industry, Helsinki

Prime Minister's Office and Economic Council (2000) Environmental and energy taxation in Finland-preparing for the Kyoto challenge. Prime Minister's Office, Helsinki

Radaelli C (2007) Whither better regulation for the Lisbon Agenda? J Eur Public Policy 14:190-207

Rogge K, Schleich J, Betz R et al (2006) Increasing the ambition of EU emissions trading. Greenpeace International, Amsterdam

Rosenau JN (1992) Governance, order and change in world politics. In: Rosenau JN, Czempiel EO (eds) Governance without government. Cambridge University Press, Cambridge

Rheinisch-Westfälisches Institut für Wirtschaftsforschung (RWI) (2000) Die Klimaschutzerklärung der Deutschen Industrie unter neuen Rahmenbedingungen. Monitoringbericht 1999. RWI, Essen

Sabatier P (1986) Top-down and bottom-up approaches to implementation research: a critical analysis and suggested synthesis. J Public Policy 6:21-48

Schön D, Rein M (1994) Frame reflection. Basic Books, New York

Sijm J, Neuhoff K, Chen Y (2006) $\mathrm{CO}_{2}$ cost pass-through and windfall profits in the power sector. Clim Policy 6:49-72

Sorrell S, Sijm J (2003) Carbon trading in the policy mix. Oxford Rev Econ Pol 19:420-437

Sachverständigenrat für Umweltfragen (SRU) (2000) Umweltgutachten 2000. Schritte ins nächste Jahrtausend. SRU, Berlin

SRU (2004) Umweltgutachten 2004. Umweltpolitische Handlungsfähigkeit sichern. SRU, Berlin

SRU (2005) Umwelt und Strassenverkehr. Hohe Mobilität-Umweltverträglicher Verkehr. SRU, Berlin

Stufflebeam D (2001) The metaevaluation imperative. Am J Eval 22:183-209

Symons EJ, Speck S, Proops J (2002) The distributional effects of carbon and energy taxes. Eur. Environ. 12:203-212

Szarka J, Blühdorn I (2006) Wind power in Britain and Germany. Anglo-German Foundation for the Study of Industrial Society, London

Tiezzi S (2005) The welfare effects and the distributive impact of carbon taxation on Italian households. Energy Policy 12:1597-1612

Wissenschaftlicher Beirat beim Bundesministerium für Wirtschaft und Arbeit (WBBWA) (2004) Zur Förderung Erneuerbarer Energien. Federal Ministry for Economics and Labour, Berlin 
Weidner H (2005) Global equity versus public interest? Wissenschaftszentrum Berlin, Berlin Weiss C (1975) Evaluation research in the political context. In: Struening EL, Guttentag M (eds) Handbook of evaluation research, vol 1. Sage, London

Weiss C (1979) The many meanings of research utilization. Public Adm Rev 39:426-431

Wüstenhagen R, Bilharz M (2006) Green energy market development in Germany: effective public policy and emerging customer demand. Energy Policy 34:1681-1696 